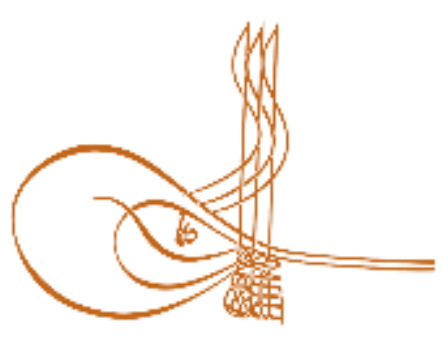

www.turkishstudies.net/social
Turkish Studies - Social Sciences

eISSN: $2667-5617$

Research Article / Araştırma Makalesi

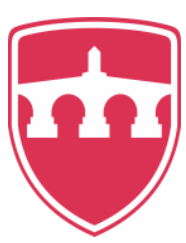

INTERNATIONAL

BALKAN

UNIVERSITY

Sponsored by IBU

\title{
Çözüm Odaklı Psikolojik Danışma Yaklaşımına Dayalı Grupla Psikolojik Danışmanın Ruminasyon ve Öğrenilmiş Çaresizlık Üzerindeki Etkisi"
}

The Effect Of Solution Focused Group Counseling On Rumination And Learned Helplessness

\author{
Mehmet Ünal ${ }^{*}$ - Diğdem Müge Siyez ${ }^{* *}$
}

\begin{abstract}
This study aimed to investigate the effect of solution focused group counseling on rumination and learned helplessness of high school students. A mixed pattern of $3 \times 3$ (experimental control placebo $x$ pretest, posttest and follow-up test) was used in the study. The research was carried out in three Anatolian high schools located in the Altieylül district of the Balıkesir province in the spring semester of the 2016-2017 academic year. 10th and 11th grade students of three Anatolian High Schools with similar characteristics were included in the study group of the research. A total of 30 students, 10 in the experimental, placebo and control groups, participated in the study. While the solution focused group counseling sessions were conducted with the experimental group, no application was made to the control group and vocational guidance activities were conducted with the placebo group. The basic principles and techniques of the solution-focused brief therapy were utilized while the solution-focused group counseling sessions were structured and 90 minutes were allocated to each session. The vocational guidance activities applied to the placebo group consist of 6 sessions lasting 40 minutes. In the research, "The Rumination Scale" and "The Learned Helplessness Scale" were used as data collection tools. Multivariate ANOVA (MANOVA) analysis was used to test the effectiveness of the program. As a result of the research, the program which effectiveness was examined, was found to reduce high school students rumination and learned helplessness levels. The findings were discussed based on the literature.
\end{abstract}

Structured Abstract: Adolescence is a period of significant and rapid physiological, psychological and social developments, stress and confusion intensified, difficulties in relationships with family and peers,

* Bu makale Dokuz Eylül Üniversitesi Eğitim Bilimleri Enstitüsü'nde Prof. Dr. Diğdem Müge SİYEZ'in danışmanlığında Mehmet ÜNAL tarafından yürütülen "Çözüm Odaklı Psikolojik Danışma Yaklaşımına Dayalı Grupla Psikolojik Danışmanın Ruminasyon ve Öğrenilmiş Çaresizlık Üzerindeki Etkisi” başlıklı doktora tezinden üretilmiştir.

* Doktora Öğrencisi, Dokuz Eylül Üniveristesi Eğitim Bilimleri Enstitüsü

PhD Student, Dokuz Eylül Univeristy Institute of Educational Sciences

ORCID 0000-0002-8432-6715

una13334@hotmail.com

** Prof. Dr., Dokuz Eylül Üniveristesi, Buca Eğitim Fakültesi, Eğitim Bilimleri Bölümü

Prof. Dr., Dokuz Eylül Univeristy, Buca Faculty of Education, Department of Educational Sciences ORCID 0000-0003-4724-3387

didem.siyez@deu.edu.tr

Cite as/ Atıf: Ünal, M., Siyez, D.M. (2020). Çözüm odaklı psikolojik danışma yaklaşımına dayalı grupla psikolojik danışmanın ruminasyon ve öğrenilmiş çaresizlık üzerindeki etkisi, Turkish Studies - Social, 15(1), 733-752. https://dx.doi.org/10.29228/TurkishStudies.39848

Received/Geliş: 21 November/Kasım 2019

Accepted/Kabul: 25 February/Şubat 2020

Checked by plagiarism software

Copyright $($ INTAC LTD, Turkey 
change of peers at school, demands and expectations about education, changes in ideas such as making choices about school and career. They have to deal with differentiated problems it is a period of reaching from childhood to adulthood and a long transition (Özyurt, 2010; Yavuzer, 2005).

During this period, adolescents can experience a number of behavioral and emotional changes, such as being excited quickly, wanting to be alone, unwillingness to work, excessive flight of fancy. During adolescence, young person may live problems such as depression, anxiety disorders or substance use (Abela, Vanderbilt and Rochon, 2004). The adolescent faces new roles and responsibilities, reviewing their relationship with adults, their peers, and society. In this process, it is also observed that the adolescent may go towards to behaviors that involve risks that endanger their health and relationships (Carr-Gregg, Enderby and Grover, 2004; as cited İkiz and Çınkı, 2016).

It is suggested that some adolescents are more prone to experience these problems when it is considered that not all adolescents in adolescence experience psychological problems only some of them experience these problems (Siyez, 2010). According to Response Styles Theory (Nolen Hoeksema, 1991), which is very popular in recent years, the tendency of adolescents to experience psychological problems is explained by their ruminative personality traits.

Rumination is defined as a negative and repetitive focus on the psychological symptoms of a person's distress without actively attempting to correct certain problems (Nolen Hoeksema, Girgus and Seligman 1986). In another definition, rumination is described as stubborn, repetitive, depressive thought related to negative mood (Rippera, 1997).

Another factor that plays a role in comprise of psychological problems of adolescents is the learned helplessness (Seligman, 2007). Learned helplessness is one's perception of himself as inadequate in overcoming failure and one's belief that the consequences of events are unconnected of his own actions (Ellis, 2005). Studies in the literature indicate that children who have learned a sense of helplessness tend to explain their failures with a lack of talent rather than a lack of effort. Children with learned helplessness internalize their failures, see failure as a constant and relatively unchangeable thing, and believe that they will fail because they lack the innate ability to succeed, no matter how hard they try to solve a problem (Dwayne, 1996; Ellis, 2005).

The most common feature of individuals with ruminative and individuals who learned learned helplessness; they are stuck with negative effects for a long time and are pessimistic about the future by concentrating on the negative sides of the events. Inability to establish healthy social relations, low academic achievement are other common features experienced by individuals with ruminative and learned helplessness. In short, rumination and learned helplessness negatively affect the psychosocial development of individuals. Therefore, reducing rumination and learned helplessness is an important issue for adolescent mental health.

Solution-focused counseling does not care about emphasizing past mistakes. Instead, it focuses on the client's strength and past achievements. It assumes that there are no problems at all, exceptions that problems may sometimes occur but in some cases do not. The consultant discover what is different in the exception at the time the problem arises. The aim is to try to strengthen these differences (Quick, 2013).

Lambert, Okiishi, Finch and Johnson (1998) investigated the effect of solution-focused counseling in reducing anxiety. It was found that the solution-focused method and psychological counseling with the group that continued for one hour and three weeks per week reduced anxiety (as cited Gingerich and Eisengart, 2000). İşlek (2006) concluded that the training program for coping with exam anxiety, which was arranged according to a solution-focused approach, reduced the exam anxiety scores of students preparing for university exams. Bulut-Saric1 (2008) found that the solution-focused counseling approach reduced the level of exam anxiety among the secondary school students. Gingerich and Wabeke (2001) reported that solutionfocused counseling was effective in mental health problems such as depression and anxiety disorders.

As a result of the literature review, the number of studies about rumination in our country is very limited. It is thought that conducting a research on this subject will be the source for new researches in the literature since there is no group study on rumination and learned helplessness. It is thought that experimental studies are needed to determine the correct interventions for adolescents to cope with rumination and learned helplessness. It is believed that this group counseling, which is prepared for adolescents will make important

Turkish Studies - Social, 15(1) 
contributions to the adolescents to recognise themselves better, to notice their talents and interests, to establish healthy interpersonal relationships, to gain self-confidence and psychosocial adaptation.

Counseling sessions were formed with a solution focused group for high school students, implemented for 6 weeks, and the effectiveness of the program was tested. It is aimed to contribute to the literature of psychological counseling and guidance by presenting suggestions in line with the results of the research.

The main problem of the study is "Does solution focused group counseling effects the rumination and learned helplessness levels of high school students?".

\section{Method}

In this research, $3 \times 3$ split (split plot) mixed pattern was used. In this pattern, the first factor shows the experimental process groups (experimental, placebo and control groups) and the second factor shows the repeated measures (pretest, posttest and follow-up measures) of the dependent variable (Büyüköztürk, 2012).

The research was carried out in three Anatolian high schools located in Altıeylül district of Balıkesir province in the spring semester of 2016-2017 academic year. 30 students (10 in the experimental, placebo and control groups) participated in the study. The study continued 6 weeks with the experimental group, Solution-focused group counseling were conducted, no application was conducted with the control group and vocational guidance activities were conducted with-the placebo group. In the research, "The Rumination Scale" adapted to Turkish by Erdur-Baker (2009) and "The Learned Helplessness Scale" adapted to Turkish by Aydın (1988) were used as data collection tools. Multivariate ANOVA (MANOVA) analysis was used for data analysis. Data were analyzed using SPSS analysis program.

\section{Findings}

It was studied with MANOVA whether there was a statistically significant difference between the mean scores obtained from pre-test, final test and follow-up test measurements of the rumination and learned helplessness scales of the students in the experiment, placebo and control groups.

When the group variable was evaluated, Wilks 'Lambda $(T=.301, p=.004)$ values were found to be significant. According to this, it can be said that the solution focused group counseling have an effect on the rumination and learned helplessness levels of high school students.

For the rumination scale, there was a significant difference between the pre-test, sontest and followup test score averages of the experimental groups $(\mathrm{p}<0.05)$. There was no significant difference between the pre-test, final test and follow-up test score averages of the placebo group $(\mathrm{p}=0.182>0.05)$. There was no significant difference between the pre-test, final test and follow-up test score averages of the control group $(\mathrm{p}=0.115>0.05)$.

For the learned helplessness scale, there was a significant difference between the pre-test, final test and follow-up test score averages of the experimental groups $(\mathrm{p}=0.011<0.05)$. There was no significant difference between the preest, final test and follow-up test score averages of the placebo group $(\mathrm{p}=0.500>0.05)$. There was no significant difference between the pre-test, final test and follow-up test score averages of the control group $(\mathrm{p}=0.854>0.05)$.

The source of the difference between the groups in relation to the rumination test is examined by the experimental group pre-test $(\overline{\mathrm{X}}=32.30$. $\mathrm{ss}=4.32)$ with experimental group final test $(\overline{\mathrm{X}}=23.70$. $\mathrm{ss}=3.62)$ and follow-up test $(\bar{X}=24.40$. ss $=3.24$ ) it can be said that there was a significant difference between the mean scores and that there was a significant decrease in the rumination scores of the students in the experimental group between the pre-test and the final test and the pre-test and the follow-up test. There was no significant reduction between the final test $(\overline{\mathrm{X}}=23.70$. ss $=3.62)$ and the follow-up test $(\overline{\mathrm{X}}=24.40$. ss $=$ 3.24).

The source of the difference between the groups in relation to the learned helplessness test is examined by the experimental group pre-test $(\overline{\mathrm{X}}=14.20$. $\mathrm{ss}=4.52)$ with experimental group final test $(\overline{\mathrm{X}}=$ 9.60. $\mathrm{ss}=2.88)$ and follow-up test $(\overline{\mathrm{X}}=10.10 . \mathrm{ss}=2.69)$ it can be said that there was a significant difference between the mean scores and that there was a significant decrease in the learned helplessness scores of the students in the experimental group between the pre-test and the final test and the pre-test and the follow-up 
test. There was no significant reduction between the final test $(\overline{\mathrm{X}}=9.60 . \mathrm{ss}=2.88)$ and the follow-up test testi ( $\overline{\mathrm{X}}=10.10 . \mathrm{ss}=2.69$ ).

These findings indicate that the students in the experimental group who participated in solution focused group counseling had a significant decrease in the rumination and learned helplessness scale scores compared to the placebo and control group, and that this decrease was permanent.

\section{Discussion and Conclusion}

The solution focused group counseling sessions were conducted with the experimental group, no application was made to the control group and vocational guidance activities were conducted with the placebo group.

As a result of the research, it was found that there was a significant decrease in the levels of rumination and learned helplessness of the students who participated in the solution focused group counseling (experimental group). There was no significant decrease in rumination and learned helplessness in the control and placebo groups. According to this, it can be said that solution focused group counseling is effective in decreasing rumination and learned helplessness levels of high school students.

In the first hypothesis of the study, the rumination levels of the the experimental, placebo and control groups were examined. The rumination levels of the students who participated in solution focused group counseling would be significantly lower than the rumination levels of the participants in the placebo and control group who did not participate in this program. This difference will continue in monitoring measurements to be made one month after the completion of the sessions. The findings confirm the first hypothesis of the study. According to this, it can be said that solution focused group counseling is effective in decreasing rumination levels of high school students. A similar study was conducted by Sarıçam (2014) that has shown that a Solution Focused Group Counseling reduces the level of rumination of university students and this situation is maintained in the persistence measurements. This result is consistent with the findings of the study.

There is no other study in the literature examining the effect of Solution Focused Counseling Approach on rumination. Therefore, studies investigating the effect of other intervention approaches on rumination were examined. The results of the studies aimed at reducing rumination are similar to the findings of this study. Ramel, Goldin, Carmona, and McQuaid (2004) reported that awareness meditation reduced rumination. Similarly, there are studies showing that cognitive behavioral therapy is effective in reducing rumination (Watkins, Scott, Wingrove, Rimes, Bathurst et al. (2007); Watkins, Mullan, Wingrove, Rimes, Steiner et al. (2011).

There are studies showing that rumination is associated with anxiety (Alloy et al, 2006; Ko, Yu and Kim, 2003;) problem solving and depression (Yıldız and Erdeleklioğlu, 2017; Lyubomirsky et al., 1999), anxiety and depression (Erdur-Baker, Özgülük, Turan and Konuşı). Lambert, Okiishi, Finch and Johnson (1998), Gingerich and Eisengart (2000), İşlek (2006) reported that psychological counseling based on a solution-focused counseling is effective in reducing anxiety. Sarıcı-Bulut (2008) reported that solutionfocused counseling is effective in, exam anxiety and problem solving skills of the second grade students; Sarı and Günaydın (2016) concluded that it was effective in reducing depressive symptoms.

In the second hypothesis of the study, the learned helplessness levels of the the experimental, placebo and control groups were examined. The learned helplessness levels of the students who participated in solution focused group counseling would be significantly lower than the rumination levels of the participants in the placebo and control group who did not participate in this program. This difference will continue in monitoring measurements to be made one month after the completion of the sessions. The findings confirm the second hypothesis of the study. According to this, it can be said that solution focused group counseling is effective in decreasing the learned helplessness levels of high school students. Kök (1992); Avc1, (2009); Kezele (1985) concluded that, the group counseling and psycho-education has an effect on reducing learned helplessness. The results of the research show similarity with the findings in the literature.

Adolescence is a period that; individuals' evaluations and feedbacks are highly emphasized. Solution Focused Group Counseling techniques such as cheerleading and complimenting were effective on the students. In addition, it is observed that students take action to solve their problems through methods such as 
focusing on situations where there is no problem, talking about what needs to be done to reach a solution, encouraging throwing towards solution, focusing on internal resources, and discovering strengths. Thus, it can be said that it enables them to make efforts and take steps towards solving negative situations caused by ruminative thoughts and learned helplessness feelings.

In the group process, adolescents shared their problems with the group members, tried to understand their feelings and thoughts by listening to each other's problems, saw that other friends had similar problems and tried to support each other. It can be said that the therapeutic relationship in group counseling has an effect on reducing adolescents rumination and learned helplessness. The fact that the group leader had previously conducted the Psychological Counseling sessions with the Solution Focused Group and that he had piloted with a similar group before the actual practice could be seen as positive in terms of gaining experience and recognizing the characteristics and dynamics of the group. Inclusion of the placebo group in the study and conducting vocational guidance studies in the placebo group may be considered important to test whether the differences in the experimental group score are due to group effect.

This study has some limitations. Only quantitative data were used as data collection method. The use of qualitative data (participant diaries, etc.) as well as quantitative data can lead to stronger research results. In this study, retention was measured 1 month after the last test. Failure to measure retention after 6 months or 1 year is one of the limitations of the study.

\section{Suggestions}

When the research findings are considered, it may be useful to use the solution-focused counseling, which provide effective results in a short time, in solving the problems of the students in the school guidance units.

In-service courses should be organized for school counselors to develop their knowledge and skills related to the solution-focused counseling.

This is the first study in the literature on the effect of solution-focused group counseling on learned helplessness. After that, the researches can be done with different sample groups. Thus, its effectiveness is tested in different groups.

The effectiveness of the same program can also be tested in different groups and diagnosed individuals.

In our country, it is observed that there are few experimental studies conducted with rumination and learned helplessness. It is thought to be beneficial to examine the effects of experimental studies with Solution Focused Counseling or other approaches on rumination and learned helplessness.

Keywords: Psychological counseling and guidance, Solution Focused Group Counseling, Rumination, Learned Helplessness, Adolescence.

Öz: Bu çalışmanın amacı, çözüm odaklı psikolojik danışma yaklaşımına dayalı grupla psikolojik danışmanın lise öğrencilerinin ruminasyon ve öğrenilmiş çaresizlik düzeyleri üzerindeki etkisini incelemektir. Çalışmada 3x3' lük (deney kontrol plasebo x ön test son test izleme testi) karışık desen kullanılmıştır. Araştırma, 20162017 eğitim öğretim yılının bahar yarıyılında Balıkesir ili Altıeylül ilçesinde bulunan üç Anadolu lisesinde gerçekleştirilmiştir. Araştırmanın çalışma grubuna birbirine benzeyen özelliklere sahip üç farklı Anadolu Lisesinin 10. ve 11. sınıf öğrencileri dahil edilmiştir. Çalışmaya deney, plasebo ve kontrol grubunda 10'ar olmak üzere toplam 30 öğrenci katılmıştır. Deney grubunda 6 oturumluk çözüm odaklı danışma yaklaşımına dayalı grupla psikolojik danışma oturumları yürütülmüş, kontrol grubunda herhangi bir uygulama yapılmamış, plasebo grubunda ise deney grubuyla paralel zaman diliminde mesleki rehberlik etkinlikleri gerçekleştirilmiştir. Çözüm odaklı grupla psikolojik danışma oturumları yapılandırılırken çözüm odaklı kısa süreli terapi yaklaşımın temel ilke ve tekniklerinden yararlanılmış ve her bir oturuma 90 dakika süre ayrılmıştır. Plasebo grubuna uygulanan mesleki rehberlik etkinlikleri ise her biri 40 dakika süren 6 oturumdan oluşmaktadır. Araştırmada veri toplama aracı olarak "Ruminasyon Ölçeği” ile "Öğrenilmiş Çaresizlik Ölçeği” kullanılmıştır. Programın etkililiğini test etmek için çok değişkenli ANOVA (MANOVA) analizi kullanılmıştır. Araştırma sonucunda etkililiği incelenen programın lise öğrencilerin ruminasyon ve öğrenilmiş çaresizlik düzeylerini azalttığı görülmüştür. Elde edilen bulgular alan yazına dayalı olarak tartışılmıştır. 
Anahtar Kelimeler: Psikolojik danışmanlık ve rehberlik, Çözüm odaklı grupla psikolojik danışma, Ruminasyon, Öğrenilmiş çaresizlik, Ergenlik.

\section{Giriș}

Ergenlik, hızlı fizyolojik, psikolojik ve sosyal gelişimlerin görüldüğü, çok da belirli olmayan bir zamanda sona eren stres ve karmaşanın yoğunlaştığı, aile ve yaşıtlar ile olan ilişkilerde zorluklar, karşı cinsle olan ilişkide güçlükler, okulda arkadaşlık ettiği yaşıtların değişmesi, eğitimle ilgili talepler ve beklentiler, okul ve kariyer hakkında seçim yapmak gibi fikir değişikliklerinin yaşandığ 1 çocukluktan yetişkinliğe atlama ve uzun bir geçiş dönemidir. (Özyurt, 2010; Yavuzer, 2005).

Ergenler bu dönemde çabuk heyecanlanma, yalnız kalmak isteme, çalışmaya karşı isteksizlik, aşırı hayal kurma gibi davranışsal ve duygusal birtakım olumsuzluklar yaşayabilirler. Ergenin yaşadığı bu olumsuz duygular depresyon, kaygı bozuklukları veya madde kullanımı gibi sorunları beraberinde getirebilmektedir (Abela, Vanderblit ve Rochon, 2004). Bu süreçte, ergen, sağlığını ve çevresiyle olan ilişkisini tehlikeye atabilecek riskli davranışlar sergileyebilmektedir. (Carr-Gregg, Enderby ve Grover,2004; akt. İkiz ve Çınkı, 2016).

Ergenlik dönemindeki tüm ergenlerin psikolojik sorunlar yaşamadığı sadece bazılarının bu sorunları yaşadığı dikkate alındığında bazı ergenlerin bu sorunları yaşamaya daha eğilimli olduğu ileri sürülmektedir (Siyez, 2010). Ergenlerin yaşadıkları psikolojik sorunların nedenlerini açıklamaya yönelik biyolojik temelli, sosyolojik temelli ve psikoloji temelli pek çok yaklaşım ileri sürülmektedir. Son yıllarda oldukça popüler olan psikoloji temelli Tepki Stilleri Kuramı'na (Nolen Hoeksema, 1991) göre ergenlerin psikolojik sorunlar yaşamaya daha eğilimli olması ruminatif kişilik özellikleri ile açıklanmaktadır. Ruminasyon, kişinin belirli problemleri düzeltmek için aktif olarak çaba göstermeksizin sıkıntısının psikolojik belirtileri üzerine olumsuz ve tekrarlayan bir şekilde odaklanması olarak tanımlanmaktadır (Nolen Hoeksema, 1991, Girgus ve Seligman 1986). Bir başka tanımda ise ruminasyon olumsuz ruh haliyle ilişkili olan inatçı, tekrar edici, depresif düşünce olarak tarif edilmektedir (Rippera, 1997). Papagergiou ve Wells (2004); "Neden sadece bir kaybedenim", "Ruh halim çok kötü", "Neden hep olumsuz tepki veriyorum", "Hiçbir şeyle baş edemiyorum", "Neden herhangi bir şey yaparken iyi hisstmiyorum" gibi cümleleri ruminatif düşüncelere örnek olarak göstermektedir.

Ergenlerin psikolojik problemlerinin ortaya çıkmasında rol oynayan bir diğer faktör olarak karşımıza öğrenilmiş çaresizlik çıkmaktadır (Seligman, 2007). Öğrenilmiş çaresizlik, kişinin başarısızlığın üstesinden gelmede kendini yetersiz olarak algılaması ve kişinin, olayların sonuçlarının kendi eylemlerinden bağımsız olduğuna olan inancıdır. Ellis (2005)'e göre öğrenilmiş çaresizliğin temelinde bireyin pasifliği, eyleme geçememesi ve bireyin yaşamını kontrol edememe duygusu yer almaktadır. Alan yazında yer alan çalışmalar, öğrenilmiş çaresizlik duygusu yaşayan ergenlerin başarısızlıklarını çaba eksikliğinden ziyade yetenek eksikliği ile açıklama eğiliminde olduklarını göstermektedir. Öğrenilmiş çaresizliği olan çocukların yaşadıkları başarısızlıkları içselleştirdikleri, başarısızlığı sürekli ve nispeten değişmez bir şey olarak gördükleri ve bir problemi çözerken ne kadar çaba gösterirse göstersin başarılı olmak için doğuştan gelen yetenekten yoksun oldukları için başarısız olacağına inandıkları alan yazında yer alan bilgiler arasında yer almaktadır (Dwayne, 1996; Ellis, 2005).

Ruminatif yatkınlı̆̆ 1 olan bireylerle öğrenilmiş çaresizlik yaşayan bireylerin en belirgin ortak özelliği; olumsuz etkilere daha uzun süre takılı kalmaları ve olayların olumsuz taraflarına yoğunlaşarak gelecek hakkında karamsar olmalarıdır. Sağlıklı sosyal ilişkiler kuramamaları, akademik başarılarının düşük olması ruminatif düşünen ve öğrenilmiş çaresizliği olan bireylerin yaşadığ 1 diğer ortak özelliklerdendir. Özetle ruminasyon ve öğrenilmiş çaresizlik bireylerin psiko- 
sosyal gelişimlerini olumsuz yönde etkilemektedir. $\mathrm{Bu}$ nedenle ruminasyon ve öğrenilmiş çaresizlik düzeyinin azaltılması ergenin ruh sağlığı açısından önemli görülmektedir.

Yurt içinde Sarıçam (2014) tarafından geliştirilen Çözüm Odaklı Kısa Süreli Yaklaşıma Dayalı Bir Müdahale Programı'nın üniversite öğrencilerinin ruminasyon düzeylerini azalttığı rapor edilmiştir. Yurt dışında ise farkındalık meditasyonunun (Ramel, Goldin, Carmona ve McQuaid, 2004), bilişsel-davranışçı terapinin (Watkins, Scott, Wingrove, Rimes, Bathurst ve diğerleri, 2007; Watkins, Mullan, Wingrove, Rimes, Steiner ve diğerleri, 2011) etkili olduğu saptanmıştır. Yurt içinde, Kök (1992) çocuk esirgeme kurumundaki çocuklarla yapılan grupla psikolojik danışma müdahalesinin; Avc1, (2009) ortaöğretim öğrencileri ile yapılan psiko-eğitim programının; öğrenilmiş çaresizlik üzerinde etkili olduğunu; Ulusoy ve Duy (2013), öğrenilmiş iyimserlik psikoeğitim uygulamasının ilköğretim öğrencilerinde öğrenilmiş çaresizliği azaltmada anlamlı bir etkisinin olmadığı sonucuna ulaşmışlardır. Yurt dışında ise Kezele (1985) öğrenilmiş çaresizliği azaltmaya odaklanan bir psiko-eğitim uygulamasının öğrencilerin öğrenilmiş çaresizlik algılarını değiştirmeyi başardığı; Houlihan (1981) uygulanan atılganlık eğitiminin öğrenilmiş çaresizlik üzerinde etkili olmadığını rapor etmiştir (akt. Ulusoy ve Duy, 2013).

Okul psikolojik danışmanlığı alanında sıklıkla kullanılan psikolojik danışma yaklaşımlarından biri olan çözüm odaklı psikolojik danışma, geçmişteki yanlışlar ve hatalar yerine danışanın güçlü yanları ve geçmiş başarıları üzerine odaklanır. Okullarda öğrenci sayısının fazla olması, psikolojik danışmanların sürelerinin sınırlı olması; hem maliyet hem zaman açısından ekonomik olan çözüm odaklı kısa psikolojik danışma modelini diğerlerine göre daha avantajlı kılmaktadır. Amaç belirleme, mucize sorunun kullanımı, istisnai anların belirlenmesi çözüm odaklı yaklaşımı geleneksel yaklaşımlardan ayıran belli başlı özellikler arasında yer almaktadır (Quick, 2013). Kısa süreli olması, gelişimsel olarak olumlu özelliklere vurgu yapması ve yapılandırılmış olması nedeniyle okul temelli grup müdahalelerinde de çözüm odaklı psikolojik danışma yaklaşımı sıklıkla kullanılmaktadır. Nitekim Gingerich ve Wabeke (2001) okullarda öğrencilerin karşılaştıkları problemlerin çözümünde çözüm odaklı yaklaşımın etkililiğini değerlendirdikleri araştırmalarında bu yaklaşımın depresyon ve kaygı sorunlarının azaltılmasında etkili olduğunu rapor etmektedirler. Lambert, Okiishi, Finch ve Johnson (1998) tarafından yapılan bir çalışmada ise bu yaklaşımın kaygıyı azaltmadaki etkisi incelenmiş ve çözüm odaklı grupla psikolojik danışmanın kaygıyı azalttığı belirlenmiştir (Akt. Gingerich ve Eisengart, 2000). Bulut-Sarıcı (2008) tarafından yapılan bir araştırmada da, çözüm odaklı psikolojik danışma yaklaşımının ilköğretim ikinci kademe öğrencilerinin sınav kaygısı düzeylerini düşürdüğü belirlenmiştir.

Ergenlerin ruminasyon ve öğrenilmiş çaresizlik durumlarıyla başa çıkabilmeleri için doğru müdahaleleri belirlemeye yönelik deneysel çalışmalara ihtiyaç olduğu düşünülmektedir. Duygusal iniş çıkışların sıkça yaşandığı ergenlik döneminde, ergenlere yönelik olarak hazırlanan bu eğitim programının ergenlerin kendilerini daha yakından tanımalarına, yetenek ve ilgilerinin farkına varmalarına, sağlıklı kişilerarası ilişkiler kurabilmelerine, özgüven kazanmalarına, psiko-sosyal uyumlarına önemli katkılar sağlayacağına inanılmaktadır. Ancak yapılan alanyazın taraması sonucunda özellikle ruminasyonla ilgili ülkemizde yapılan çalışmaların sayısı oldukça azdır. Ruminasyon ve öğrenilmiş çaresizliğin bir arada ele alınarak yapıldığı herhangi bir grup çalışmasına rastlanmaması bu konuda yapılacak bir araştırmanın alan yazına önemli katkı sağlayacağı düşünülmektedir.

Bu bağlamda bu araştırmanın amacı, çözüm odaklı psikolojik danışma yaklaşımına dayalı grupla psikolojik danışmanın lise öğrencilerinin ruminasyon ve öğrenilmiş çaresizlik düzeyleri üzerindeki etkisinin incelenmesidir. Araştırmanın amacı doğrultusunda araştırma sorusu şu şekilde oluşturulmuştur.

Denence 1: Çözüm odaklı grupla psikolojik danışma yaklaşımına dayalı grupla psikolojik danışma oturumlarına katılan öğrencilerin ruminasyon ön test, son test puan ortalamalarında 
plasebo ve kontrol grubundaki öğrencilere göre istatistiksel olarak anlamlı bir düşüş olacaktır ve bu düşüş izleme testinde de korunacaktır.

Denence 2: Çözüm odaklı grupla psikolojik danışma yaklaşımına dayalı grupla psikolojik danışma oturumlarına katılan öğrencilerin öğrenilmiş çaresizlik ön test, son test puan ortalamalarında plasebo ve kontrol grubundaki öğrencilere göre istatistiksel olarak anlamlı bir düşüş olacaktır ve bu düşüş izleme testinde de korunacaktır.

\section{Yöntem}

\subsection{Araştırma Modeli}

Araştırmada 3x3' lük (split plot) karışık desen kullanılmıştır. Birinci etmen deneysel işlem gruplarını (deney, kontrol, plasebo grubu) ikinci etmen ise bağımlı değişkenin tekrarlı ölçümlerini (ön test, son test ve kalıc1lı ölçümü) göstermektedir. Araştırma modeli Tablo 1'de yer almaktadır.

Tablo 1: Araştırma Modeli

\begin{tabular}{|c|c|c|c|c|}
\hline Gruplar & Ön Test & İşlem & Son Test & Kalıcılık Ölçümü \\
\hline Deney & $\begin{array}{c}\text { RÖ } \\
\text { ÖÇÖ }\end{array}$ & $\begin{array}{c}\text { Çözüm Odaklı Psikolojik } \\
\text { Danışma Yaklaşımına Dayalı } \\
\text { Grupla Psikolojik Danışma } \\
\text { Programı }\end{array}$ & $\begin{array}{c}\text { RÖ } \\
\text { ÖÇÖ }\end{array}$ & $\begin{array}{c}\text { RÖ } \\
\text { ÖÇÖ }\end{array}$ \\
\hline Plasebo & $\begin{array}{c}\text { RÖ } \\
\text { ÖÇÖ }\end{array}$ & Mesleki Rehberlik Programı & $\begin{array}{c}\text { RÖ } \\
\text { ÖÇÖ }\end{array}$ & $\begin{array}{c}\text { RÖ } \\
\text { ÖÇÖ }\end{array}$ \\
\hline Kontrol & $\begin{array}{c}\text { RÖ } \\
\text { ÖÇÖ }\end{array}$ & - & $\begin{array}{c}\text { RÖ } \\
\text { ÖÇÖ }\end{array}$ & $\begin{array}{c}\text { RÖ } \\
\text { ÖÇÖ }\end{array}$ \\
\hline
\end{tabular}

* RÖ Ruminasyon Ölçeği

* ÖÇÖ Öğrenilmiş Çaresizlik Ölçeği

\section{2. Çalışma grubu}

Araştırmada deney, plasebo ve kontrol gruplarındaki katılımcıları belirlemek maksadıyla Balıkesir İli Altıeylül ilçesinde bulunan Anadolu Liselerinin Lise 2 ve Lise 3'üncü sınıfinda öğrenim gören 709 öğrenciye Ruminasyon Ölçeği ve Öğrenilmiş Çaresizlik Ölçeği uygulanmıştır. İlçede bulunan dört Anadolu Lisesinden üçü deney, kontrol ve plasebo grupları için yansız olarak kura yöntemiyle belirlenmiştir. Burada bulaşma etkisini azaltarak diş geçerliği kontrol etmek amaçlanmıştır. Öğrencilerin seçiminde ilk olarak hem ruminasyon ölçeği hem de öğrenilmiş çaresizlik ölçeğinden ortalamanın bir standart sapma üzerinde puan alan öğrenciler belirlenmiştir. Ardından her bir okul için ruminasyon ve öğrenilmiş çaresizlik puanları yüksek öğrencilerle birinci yazar tarafından bireysel görüşme yapılarak, çalışmayla ilgili bilgi verilmiş ve araştırmaya gönüllü olarak katılmak isteyen öğrenciler belirlenmiştir. Deney, kontrol ve plasebo gruplarından 10'ar öğrenci çalışmaya katılmaya gönüllü olmuşlardır. 
Tablo 2: Çalışmaya Katılan Öğrencilere Ait Bilgiler

\begin{tabular}{lcccccc}
\hline & \multicolumn{2}{c}{ Deney } & \multicolumn{2}{c}{ Kontrol } & \multicolumn{2}{c}{ Plasebo } \\
\hline \multicolumn{1}{r}{} & $\mathrm{f}$ & $\%$ & $\mathrm{f}$ & $\%$ & $\mathrm{f}$ & $\%$ \\
\hline Cinsiyet & & & & & & \\
Kiz & 5 & 50 & 5 & 50 & 5 & 50 \\
Erkek & 5 & 50 & 5 & 50 & 5 & 50 \\
Toplam & 10 & 100 & 10 & 100 & 10 & 100 \\
\hline Sinıf & & & & & & \\
10. sinıf & 5 & 50 & 5 & 50 & 5 & 50 \\
11. sinıf & 5 & 50 & 5 & 50 & 5 & 50 \\
Toplam & 10 & 100 & 10 & 100 & 10 & 100 \\
\hline
\end{tabular}

\section{3 Çözüm Odaklı Psikolojik Danışma Yaklaşımına Dayalı Grupla Psikolojik Danışma Oturumlarının Geliştirilmesi}

Çözüm Odaklı Yaklaşıma Dayalı Grupla Psikolojik Danışma oturumları 6 oturum olarak yapılandırılmıştır. Oturumların yapılandırılmasında ve tekniklerin kullanımında yurt içi ve yurt dışı ilgili literatürden (Tuna, 2012; Ateş, 2014, Uysal, 2014; İlbay, 2014; Çitemel, 2014; Sarıçam, 2014; Taylor, 2013; Zhang, Yan, Du ve Liu, 2014; Beauchemin, 2015) ve benzer programlardan yararlanılmıştır. Oturumlar boyunca beyin firtınası, anlatım, soru cevap, çeşitli etkinlikler (sevgi bombardımanı, tanışma etkinliği, oyunlar) gibi yöntemler kullanılmıştır.

Lise öğrencileri için geliştirilen oturumlarının pilot uygulaması 2015-2016 eğitim öğretim yılı 2. döneminde bir devlet Anadolu Lisesi'nde 10.sinıfa devam eden öğrencilerle yürütülmüştür. 8 öğrencinin katıldığı pilot uygulamanın her oturumundan sonra öğrencilerden oturum değerlendirme formlarını doldurmaları istenmiştir. 8 sorudan oluşan likert tipi 5'li (1=Kesinlikle katılmıyorum, $5=$ Kesinlikle katılıyorum) derecelendirmeli bir ölçme aracında; grubun süresi, içeriği, etkinliklerin faydalı olup olmadığı, grup liderinin grubu iyi yönetip yönetmediği gibi sorular mevcuttur.

Alınan geribildirimlerin ve edinilen tecrübenin 1şı̆̆ında asıl uygulamaya ilave oyun etkinlikleri dahil edilmesine, bir ders saatinin yetersiz kalmasından dolayı oturumların 90 dakika olarak planlanmasına, gruptaki öğrenci sayısının 10 öğrenci olarak belirlenmesine karar verilmiştir

\subsection{Veri Toplama Araçları}

\subsubsection{Ruminasyon Ölçeği}

Nolen-Hoeksema ve Morrow (1991) tarafindan ruminatif eğilimleri ölçmek amaciyla geliştirilen bu ölçek 21 maddelik 4'lü Likert tipi (Hiçbir Zaman, bazen, çoğunlukla, her zaman) bir ölçektir. Ölçeğin derinlemesine düşünme ve saplantılı düşünme olmak üzere 2 alt boyutu bulunmaktadır. Ölçekten alınabilecek maksimum puan 40, minimum puan ise 10 'dur. Ölçek puanının yüksekliği ruminasyonun fazlalığı anlamına gelmektedir.

Ruminasyon ölçeği'nin Türkçe uyarlaması ve geçerlik-güvenirlik çalışması Erdur-Baker ve Bugay (2012) tarafından hem lise hem de üniversite öğrencileri için incelenmiştir. Ölçeğin geçerlik çalışmaları kapsamında doğrulayıcı faktör analizi uygulanmış ve ölçeğin iki faktörlü yapıya sahip olduğu sonucuna ulaşılmıştır. Ayrıca ölçeğin tümünden ve alt maddelerinden elde edilen puanlar ile Ruminasyon Ölçeği'nin uzun formu ve Beck Depresyon Envanteri'nden elde edilen puanlarla arasındaki Pearson korelasyon katsayıları hesaplanarak ölçeğin yakınsak geçerlik çalışmaları yapılmıştır. Bu çalışmalar sonucunda korelasyonların .50 ile .91 arasında değiştiği görülmüştür. Ölçeğin güvenirlik analizleri sonucunda ise; ölçeğin tümü için Cronbach $\alpha$ iç tutarlılık 
katsayısının .85, derinlemesine düşünme alt ölçeği için .77, saplantılı düşünme alt ölçeği için ise .75 olduğu rapor edilmiştir (Erdur-Baker ve Bugay, 2012).

\subsection{2. Öğrenilmiş Çaresizlik Ölçeği}

Öğrenilmiş Çaresizlik Ölçeği’nde öğrenilmiş çaresizliği ölçmek için hazırlanan 30 madde bulunmaktadır. Ölçek puanının yüksekliği çaresizliliğin fazlalığı anlamına gelmektedir. Cronbach alfa iç tutarlık korelasyonları hem ölçeğin tümünde, hem de ayrı ayrı maddelerde hesaplanmıştır. Madde bırakma korelasyonları 0.57 ile 0.63 arasındadır. (Aydın. 1988).

Ölçek ODTÜ öğrencilerinden oluşan bir gruba dört hafta aralıkla iki defa uygulanmıştır. Deneklerin uygulamalardan aldıkları puanlar üzerinden hesaplanan Pearson momentler çarpımı katsayısı 0.65 olup bu değer $\mathrm{p}>0.001$ düzeyinde manidar bir değerdir (Aydın, 1988). Yapı geçerliği bilinen grupların puanları karşılaştırılarak test edilmiştir. Depresif yükleme biçim ölçeği nörotik depresif ve sağlıklı deneklere uygulanmış, sonuç olarak elde edilen puanlar ' $t$ ' testi kullanılarak analiz edilmiştir. İki grubun puan ortalamalarının farkının manidar olduğu sonucuna ulaşılmıştır (Aydın, 1988).

\subsection{Verilerin toplanmasi}

Uygulamalardan önce Dokuz Eylül Üniversitesi Eğitim Bilimleri Enstitüsünden etik kurul kararı, Balıkesir İl Milli Eğitim Müdürlüğü’nden gereken uygulama izinleri alınmıştır. Ardından uygulamalar birinci yazar tarafından sınıf ortamında gerçekleştirilmiştir. Bu ölçme araçlarının, öğrenciler tarafından dürüstçe yanıtlanmasını sağlamak için öğrencilere rahat ve uygun bir ortam sağlanmıştır. Her bir ölçme aracının nasıl cevaplanacağını anlatan yönergeler, ölçeğin üzerine yazılmış ve uygulama öncesinde öğrencilere, yapılan çalışmanın sonuçlarının bilimsel bir araştırmada kullanılacağı söylenmiştir. Öğrencilere veri araçları uygulanmadan önce çalışmaya katılmanın gönüllülük esasına dayandığı, çalışmaya katılmaya zorunlu olmadıkları, ölçekleri doldurmaya başlasalar bile isterlerse ölçekleri doldurmayabilecekleri belirtilmiştir. Tüm öğrenciler ölçekleri dolduracaklarını onaylamışlardır. Uygulama yaklaşık 25 dakikada tamamlanmıştır. Uygulamalar sonucunda yönergelere uygun işaretleme yapmayan veya maddeleri boş biraktığ1 tespit edilen 68 öğrencinin yanıtları analiz dışında bırakılmış ve deney, plasebo ve kontrol gruplarını oluşturacak katılımcılar toplam 641 öğrenciden elde edilen veriler arasından seçilmiştir.

\subsection{Verilerin Analizi}

Araştırmanın amacı doğrultusunda, deney, kontrol ve plasebo gruplarında yer alan deneklerin ruminasyon ve öğrenilmiş çaresizlik düzeylerinde anlamlı bir farklılık olup olmadığını test etmek amacıyla çok değişkenli ANOVA (MANOVA) analizi yapılmıştır. MANOVA bağımlı değişkenlerin bileşeninden elde edilen grup ortalama puanları arasında anlamlı fark olup olmadığını inceleyen bir tekniktir (Büyüköztürk, 2012).

MANOVA yapmadan önce takım varsayımların karşılanması gerekmektedir. İlk varsayım katılımcı sayısının birbirine eşit ya da yakın olması gerekliliğidir (Coakes, 2005; Tabachnick ve Fidell, 2001). Her bir gözenekteki n sayısı 10 olduğu için bu varsayım karşılanmıştır. İkinci varsayım her bir grupta bağımlı değişken sayısından fazla katılımcının yer almasıdır (Coakes, 2005). $\mathrm{Bu}$ araştırmanın verileri değerlendirildiğinde araştırmanın iki bağımlı değişkeni (ruminasyon düzeyi ve öğrenilmiş çaresizlik düzeyi ) olduğu görülmektedir.

Üçüncü varsayım tek değişkenli normallik ve çok değişkenli normalliktir. Tek değişkenli normallik, örneklemde bir değişkene ilişkin gözlemlerin normal dağılım gösterdiğini ifade eder. Çok değişkenli normallik ise örneklemde yer alan gözlemlerin, değişkenlerin tüm kombinasyonları açısından normal dağılım göstermesi anlamına gelir (Çokluk, Şekercioğlu ve Büyüköztürk, 2010). Araştırmanın verilerinin tek değişkenli normallik varsayımını karşılayıp karşılamadığının belirlenmesi maksadıyla Shapiro-Wilk testi sonuçlarına bakılmıştır. Verilerin normal dağılıp dağılmadığının incelenmesi için, örneklem sayısının küçük olması nedeniyle Kolmogorov Smirnov

Turkish Studies - Social, 15(1) 
testine kiyasla daha güçlü bir test olan (Razali ve Wah, 2011) Shapiro-Wilk testi tercih edilmiştir. Elde edilen bulgular Tablo 2'de yer almaktadır.

Tablo 3: Shapiro-Wilk Testi Sonuçları

\begin{tabular}{|c|c|c|c|c|c|c|c|c|}
\hline & \multicolumn{3}{|c|}{ Ön Test } & \multicolumn{2}{|c|}{ Son Test } & \multicolumn{2}{|c|}{ İzleme Testi } \\
\hline & & & \multicolumn{2}{|c|}{ Shapiro-Wilk } & \multicolumn{2}{|c|}{ Shapiro-Wilk } & \multicolumn{2}{|c|}{ Shapiro-Wilk } \\
\hline & & $\mathrm{n}$ & İstatistik & $\mathrm{p}$ & İstatistik & $\mathrm{p}$ & İstatistik & $\mathrm{p}$ \\
\hline \multirow[t]{3}{*}{ Ruminasyon Testi } & Deney & 10 & .952 & .689 & .877 & .120 & .958 & .765 \\
\hline & Plasebo & 10 & .873 & .109 & .944 & .593 & .899 & .215 \\
\hline & Kontol & 10 & .883 & .143 & .901 & .223 & .863 & .082 \\
\hline \multirow{3}{*}{$\begin{array}{l}\text { Öğrenilmiş Çaresizlik } \\
\text { Testi }\end{array}$} & Deney & 10 & .923 & .382 & .956 & .739 & .972 & .907 \\
\hline & Plasebo & 10 & 931 & .455 & 908 & .265 & .938 & .527 \\
\hline & Kontol & 10 & .879 & .126 & .901 & .226 & .900 & .218 \\
\hline
\end{tabular}

Tablo 3'de görülebileceği gibi ruminasyon ve öğrenilmiş çaresizlik testlerinde ön test, son test ve izleme puanları açısından normallik varsayımının karşılandığı görülmektedir.

MANOVA analizini kullanabilmek için gerekli görülen çok değişkenli normallik varsayımı Mahalanobis uzaklikları hesaplanarak incelenmiștir. (Coakes. 2005). Mahalonobis uzaklıklarının hesaplanmasının ardından elde edilen bulgular ki-kare tablosunda bağımlı değişkenler. 001 için verilen (k-1) kritik değerle kıyaslanmıştır. Ki-kare tablosundaki kritik değerin 24 olduğu tespit edilmiştir. Bu verilerdeki en yüksek Mahalonobis değeri (10.02) kritik değerin altında olduğundan çok değişkenli normallik varsayımının karşılandığı görülmüştür.

MANOVA için karşılanması gereken diğer varsayım doğrusallıktır. Doğrusallık sayıltısı çok değişkenli analizler açısından önemli bir sayıltıdır; çünkü çok değişkenli analiz teknikleri değişkenlerin doğrusal kombinasyonları temeline dayanmaktadır (Coakes. 2005). Saçılma diyagramı ile doğrusallık varsayımı incelenmiş ve bu matristeki dağılımların elips şeklinde dağıldıkları tespit edilmiştir. Bu durumda çok değişkenli doğrusallık varsayımın da karşılandığı görülmüştür.

Eş varyanslılık varsayımının karşılanması maksadıyla ruminasyon ve öğrenilmiş çaresizlik ölçeklerinin her biri için Box M testi kullanılmıştır. Bu test çok değişkenli normalliğe fazlasıyla duyarlı olduğundan $\mathrm{p}$ değeri $\mathrm{p}<.001$ olarak kabul edilmiştir. Ruminasyon Ölçeği içinvaryanskovaryans matrislerinin eşitliği (Box $\left.\mathrm{M}=9.334_{\mathrm{F} 6-18169}=1.389 . \mathrm{p}>0.05\right)$ test sonucu anlamlı olmadığ1 böylece varyans-kovaryans matrislerinin homojen olduğu görülmüştür. Öğrenilmiş Çaresizlik Ölçeği için varyans-kovaryans matrislerinin eşitliği (Box $\mathrm{M}=10.985 \mathrm{~F}_{6-18169}=1.634$, $\mathrm{p}>0.05$ ) test sonucu anlamlı olmadığı böylece varyans-kovaryans matrislerinin homojen olduğu görülmektedir.

Çoklu bağlantı probleminin olmaması MANOVA için gerekli olan son varsayımdır. Bağımsız değişkenlerin aralarında güçlü korelasyonların bulunması bağlantı veya çoklu bağlantı olarak tanımlanmaktadır. Veriler analiz edildiğinde $(r=.125 ; r=.187 ; r=207)$ çoklu bağlantı probleminin bulunmadığı sonucuna ulaşılmıştır. Sonuç olarak MANOVA yapabilmek için tüm varsayımların sağlandığı görülmüştür.

\section{Bulgular}

Deney, kontrol ve plasebo gruplarında yer alan deneklerin uygulama öncesi, uygulama sonrası ve bir ay sonra ruminasyon ve öğrenilmiş çaresizlik puanlarına ilişkin aritmetik ortalama ve standart sapma değerleri Tablo 4'te yer almaktadır. 
Tablo 4: Deney, Kontrol ve Plasebo Gruplarının Ruminasyon Ölçeği ve Öğrenilmiş Çaresizliği Ölçeği Aritmetik Ortalamaları ve Standart Sapma Değerleri

\begin{tabular}{llllllll}
\hline \multirow{2}{*}{ Değişkenler } & \multicolumn{2}{c}{$\begin{array}{c}\text { Deney } \\
(\mathrm{n}=10)\end{array}$} & \multicolumn{2}{c}{$\begin{array}{c}\text { Kontrol } \\
(\mathrm{n}=10)\end{array}$} & \multicolumn{2}{c}{$\begin{array}{c}\text { Plasebo } \\
(\mathrm{n}=10)\end{array}$} \\
\cline { 2 - 9 } & Ölçüm & $\overline{\mathrm{X}}$ & $\mathrm{ss}$ & \multicolumn{1}{c}{$\overline{\mathrm{X}}$} & $\mathrm{ss}$ & $\overline{\mathrm{X}}$ & $\mathrm{ss}$ \\
\hline \multirow{3}{*}{ Ruminasyon Ölçeği } & Öntest & 32.30 & 4.32 & 30.00 & 4.78 & 30.30 & 4.99 \\
& Sontest & 23.70 & 3.62 & 25.60 & 6.08 & 26.70 & 4.32 \\
& İzlemetest & 24.40 & 3.24 & 25.30 & 5.38 & 27.10 & 4.56 \\
\hline \multirow{2}{*}{ Öğrenilmiş Çaresizlik Öntest } & 14.20 & 4.52 & 15.60 & 3.27 & 14.70 & 3.83 \\
Ölçeği & Sontest & 9.60 & 2.88 & 14.60 & 3.53 & 13.20 & 4.44 \\
& İzlemetest & 10.10 & 2.69 & 15.20 & 4.96 & 12.50 & 4.35 \\
\hline
\end{tabular}

Deney, plasebo ve kontrol gruplarında bulunan deneklerin ruminasyon ve öğrenilmiş çaresizlik ölçeklerinin öntest, sontest ve izleme testi ölçümlerinden elde ettikleri puan ortalamaları arasında istatistiksek olarak anlamlı bir farklılık olup olmadığ 1 MANOVA ile incelenmiştir. Elde edilen bulgular Tablo 5 'te yer almaktadır.

Tablo 5: MANOVA Testi Sonuçları

\begin{tabular}{lllllll}
\hline Etki & & Değer & F & Hipotez sd & Sd & P \\
\hline \multirow{4}{*}{ Intercept } & Pillai's Trace & 0.99 & 515.414 & 6.00 & 22.00 & 0.000 \\
& Wilks' Lambda & 0.00 & 515.414 & 6.00 & 22.00 & 0.000 \\
& Hotelling's Trace & 140.56 & 515.414 & 6.00 & 22.00 & 0.000 \\
& Roy's Largest Root & 140.56 & 515.414 & 6.00 & 22.00 & 0.000 \\
\hline \multirow{4}{*}{ Grup } & Pillai's Trace & 0.75 & 2.345 & 12.00 & 46.00 & 0.019 \\
& Wilks' Lambda & 0.30 & 2.973 & 12.00 & 44.00 & 0.004 \\
& Hotelling's Trace & 2.07 & 3.622 & 12.00 & 42.00 & 0.001 \\
& Roy's Largest Root & 1.96 & 7.523 & 6.00 & 23.00 & 0.000 \\
\hline
\end{tabular}

Tablo 5'te görüldüğ̈̈ gibi grup değişkeni değerlendirildiğinde hem Pillai'sTrace $(\mathrm{V}=.759$, $\mathrm{p}=.019<0.05)$ hem de Hotteling's Trace $(\mathrm{V}=2.070, \mathrm{p}=.001<0.05)$ değerleri anlamlı çıkmıştır. Buna göre verilen çözüm odaklı yaklaşıma dayalı grupla psikolojik danışmanın lise öğrencilerinin ruminasyon ve öğrenilmiş çaresizlik düzeyleri üzerinde etkili olduğu söylenebilir.

Ruminasyon ve Öğrenilmiş Çaresizlik Ölçeği için her bir bağımlı değişkenin, bağımsız değişkenin alt grupları (öntest, sontest, izleme testi) arasında anlamlı bir fark olup olmadığına ilişkin bulgular Tablo 6' da yer almaktadır. 
Tablo 6: Deney, Plasebo ve Kontrol Gruplarının Ruminasyon ve Öğrenilmiş Çaresizlik Ölçeği Sonuçlarının Ön Test, Son Test ve İzleme Testi Sonuçlarına Göre Varyans Analizi Tablosu

\begin{tabular}{|c|c|c|c|c|c|c|c|}
\hline Kaynak & & $\begin{array}{l}\text { Type } \\
\text { Kareler } \\
\text { Toplamı }\end{array}$ & III ${ }_{\text {sd }}$ & $\begin{array}{l}\text { Kareler } \\
\text { Ortalamas1 }\end{array}$ & $\mathrm{F}$ & $\mathrm{p}$ & $\eta^{2}$ \\
\hline \multirow{6}{*}{$\begin{array}{l}\text { Corrected } \\
\text { Model }\end{array}$} & Rumi. Deney & $456.200^{\mathrm{d}}$ & 2 & 228.100 & 16.182 & .000 & .545 \\
\hline & Rumi. Plasebo & $77.867^{\mathrm{e}}$ & 2 & 38.933 & 1.815 & .182 & .119 \\
\hline & Rumi. Kontol & $138.467^{\mathrm{f}}$ & 2 & 69.233 & 2.341 & .115 & .148 \\
\hline & Öğ.Çar.Deney & $127.400^{\mathrm{a}}$ & 2 & 63.700 & 5.326 & .011 & .283 \\
\hline & Öğ.Çar.Plasebo & $25.267^{\mathrm{b}}$ & 2 & 12.633 & .710 & .500 & .050 \\
\hline & Öğ.Çar.Kontrol & $5.067^{\mathrm{c}}$ & 2 & 2.533 & .159 & .854 & .012 \\
\hline \multirow{6}{*}{ Intercept } & Rumi. Deney & 21547.200 & 1 & 21547.200 & 1528.572 & .000 & .983 \\
\hline & Rumi. Plasebo & 23576.033 & 1 & 23576.033 & 1099.211 & .000 & .976 \\
\hline & Rumi. Kontol & 21816.033 & 1 & 21816.033 & 737.674 & .000 & .965 \\
\hline & Öğ.Çar.Deney & 3830.700 & 1 & 3830.700 & 320.312 & .000 & .922 \\
\hline & Öğ.Çar.Plasebo & 5440.533 & 1 & 5440.533 & 305.903 & .000 & .919 \\
\hline & Öğ.Çar.Kontrol & 6870.533 & 1 & 6870.533 & 431.005 & .000 & .941 \\
\hline \multirow{6}{*}{ Grup } & Rumi. Deney & 456.200 & 2 & 228.100 & 16.182 & .000 & .545 \\
\hline & Rumi. Plasebo & 77.867 & 2 & 38.933 & 1.815 & .182 & .119 \\
\hline & Rumi. Kontol & 138.467 & 2 & 69.233 & 2.341 & .115 & .148 \\
\hline & Öğ.Çar.Deney & 127.400 & 2 & 63.700 & 5.326 & .011 & .283 \\
\hline & Öğ.Çar.Plasebo & 25.267 & 2 & 12.633 & .710 & .500 & .050 \\
\hline & Öğ.Çar.Kontrol & 5.067 & 2 & 2.533 & .159 & .854 & .012 \\
\hline \multirow{6}{*}{ Error } & Rumi. Deney & 380.600 & 27 & 14.096 & & & \\
\hline & Rumi. Plasebo & 579.100 & 27 & 21.448 & & & \\
\hline & Rumi. Kontol & 798.500 & 27 & 29.574 & & & \\
\hline & Öğ.Çar.Deney & 322.900 & 27 & 11.959 & & & \\
\hline & Öğ.Çar.Plasebo & 480.200 & 27 & 17.785 & & & \\
\hline & Öğ.Çar.Kontrol & 430.400 & 27 & 15.941 & & & \\
\hline \multirow{6}{*}{ Total } & Rumi. Deney & 22384.000 & 30 & & & & \\
\hline & Rumi. Plasebo & 24233.000 & 30 & & & & \\
\hline & Rumi. Kontol & 22753.000 & 30 & & & & \\
\hline & Öğ.Çar.Deney & 4281.000 & 30 & & & & \\
\hline & Öğ.Çar.Plasebo & 5946.000 & 30 & & & & \\
\hline & Öğ.Çar.Kontrol & 7306.000 & 30 & & & & \\
\hline \multirow{6}{*}{ Corrected Total } & Rumi. Deney & 836.800 & 29 & & & & \\
\hline & Rumi. Plasebo & 656.967 & 29 & & & & \\
\hline & Rumi. Kontol & 936.967 & 29 & & & & \\
\hline & Öğ.Çar.Deney & 450.300 & 29 & & & & \\
\hline & Öğ.Çar.Plasebo & 505.467 & 29 & & & & \\
\hline & Öğ.Çar.Kontrol & 435.467 & 29 & & & & \\
\hline
\end{tabular}

Buna göre Ruminasyon Ölçeği için deney gruplarının öntest, sontest ve izleme testi puan ortalamaları arasında anlamlı bir farklılık bulunmaktadır $(\mathrm{p}<0.05)$. Plasebo grubunun öntest, sontest ve izleme testi puan ortalamaları arasında anlamlı bir farklılık bulunmamaktadır $(\mathrm{p}=0.182>0.05)$. Kontrol grubunun öntest, sontest ve izleme testi puan ortalamaları arasinda anlamlı bir farklılık bulunmamaktadır $(\mathrm{p}=0.115>0.05)$. 
Öğrenilmiş çaresizlik ölçeği için deney gruplarının öntest, sontest ve izleme testi puan ortalamaları arasında anlamlı bir farklılık bulunmaktadır $(\mathrm{p}=0.011<0.05)$. Plasebo grubunun öntest, sontest ve izleme testi puan ortalamaları arasında anlamlı bir farklılık bulunmamaktadır $(\mathrm{p}=0.500>0.05)$. Kontrol grubunun öntest, sontest ve izleme testi puan ortalamaları arasinda anlamlı bir farkl11ık bulunmamaktadır $(\mathrm{p}=0.854>0.05)$.

Ortalamalar arasında gözlenen farkın hangi gruplardan kaynaklandığını bulmak için Tukey testi yapılmıştır. Ruminasyon ve Öğrenilmiş çaresizlik testi için elde edilen fark puanları ve anlamlılık testi sonuçları Tablo 7'de yer almaktadır.

Tablo 7: Deney Grubunun Ruminasyon ve Öğrenilmiş Çaresizlik Ölçeği Sonuçlarının Ön Test, Son Test ve İzleme Testi Sonuçlarına Göre Varyans Analizi Tablosu

\begin{tabular}{|c|c|c|c|c|c|c|c|c|}
\hline \multirow{2}{*}{$\begin{array}{l}\text { Bağımlı } \\
\text { Değişken }\end{array}$} & \multirow{2}{*}{$\begin{array}{c}\text { Tukey } \\
\text { Testi }\end{array}$} & \multirow[b]{2}{*}{ Gruplar } & & \multirow{2}{*}{$\begin{array}{l}\text { Ortalama } \\
\text { Farklar1 } \\
\end{array}$} & \multirow{2}{*}{$\begin{array}{l}\text { Standart } \\
\text { Hata }\end{array}$} & \multirow[b]{2}{*}{$\mathrm{P}$} & \multicolumn{2}{|c|}{ 95\% Güven Aralığ1 } \\
\hline & & & & & & & Alt Sinır & Üst Sını \\
\hline \multirow{6}{*}{ Ruminasyon } & \multirow{6}{*}{$\begin{array}{l}\text { Deney } \\
\text { Grubu }\end{array}$} & \multirow{2}{*}{ Öntest } & Sontest & $8.60 *$ & 1.679 & .000 & 4.44 & 12.76 \\
\hline & & & İzlemetest & $7.90^{*}$ & 1.679 & .000 & 3.74 & 12.06 \\
\hline & & \multirow{2}{*}{ Sontest } & Öntest & $-8.60 *$ & 1.679 & .000 & -12.76 & -4.44 \\
\hline & & & İzlemetest & -.70 & 1.679 & .909 & -4.86 & 3.46 \\
\hline & & \multirow{2}{*}{ izlemetest } & Öntest & $-7.90 *$ & 1.679 & .000 & -12.06 & -3.74 \\
\hline & & & Sontest & .70 & 1.679 & .909 & -3.46 & 4.86 \\
\hline \multirow{6}{*}{$\begin{array}{l}\text { Öğgrenilmiş } \\
\text { Çaresizlik }\end{array}$} & \multirow{6}{*}{$\begin{array}{l}\text { Deney } \\
\text { Grubu }\end{array}$} & \multirow{2}{*}{ Öntest } & Sontest & $4.60^{*}$ & 1.547 & .016 & .77 & 8.43 \\
\hline & & & İzlemetest & $4.10^{*}$ & 1.547 & .034 & .27 & 7.93 \\
\hline & & \multirow{2}{*}{ Sontest } & Öntest & $-4.60 *$ & 1.547 & .016 & -8.43 & -.77 \\
\hline & & & İzlemetest & -.50 & 1.547 & .944 & -4.33 & 3.33 \\
\hline & & \multirow{2}{*}{ İzlemetest } & Öntest & $-4.10 *$ & 1.547 & .034 & -7.93 & -.27 \\
\hline & & & Sontest & .50 & 1.547 & .944 & -3.33 & 4.33 \\
\hline
\end{tabular}

*Anlamlılık düzeyi .05 olarak kabul edilmiştir.

Ruminasyon testi ile ilgili olarak gruplar arasındaki farkın kaynağı incelendiğinde deney grubu ön testi ( $\overline{\mathrm{X}}=32.30$. $\mathrm{ss}=4.32)$ ile deney grubu son testi $(\overline{\mathrm{X}}=23.70 . \mathrm{ss}=3.62)$ ve deney grubu izleme testi $(\bar{X}=24.40$. ss $=3.24)$ puan ortalamaları arasında anlamlı bir farklılık olduğu, buna göre deney grubundaki öğrencilerin ruminasyon puanlarında ön test ve son test ile ön test ve izleme testi arasında anlamlı bir azalma olduğu söylenebilir. Son test $(\overline{\mathrm{X}}=23.70$. $\mathrm{ss}=3.62)$ ve izleme testi $(\overline{\mathrm{X}}=$ 24.40. $\mathrm{ss}=3.24)$ arasında ise anlamlı bir azalma bulunmamaktadır. Öğrenilmiş çaresizlik testi ile ilgili olarak gruplar arasındaki farkın kaynağ 4.52) ile deney grubu son testi $(\bar{X}=9.60$. $\mathrm{ss}=2.88)$ ve deney grubu izleme testi $(\overline{\mathrm{X}}=10.10$. $\mathrm{ss}=$ 2.69) puan ortalamaları arasında anlamlı bir farklılık olduğu buna göre buna göre deney grubundaki öğrencilerin öğrenilmiş çaresizlik puanlarında ön test ve son test ile ön test ve izleme testi arasında anlamlı bir azalma olduğu söylenebilir. Son test $(\bar{X}=9.60$. $s s=2.88)$ ve izleme testi $(\bar{X}=10.10$. $s s=$ 2.69) arasında ise anlamlı bir azalma bulunmamaktadır.

Bu bulgular Çözüm Odaklı Grupla Psikolojik Danışma Yaklaşımına Dayalı Grupla Psikolojik Danışmaya katılan deney grubundaki öğrencilerinin, plasebo ve kontrol grubundaki öğrencilere göre Ruminasyon Ölçeği ve Öğrenilmiş Çaresizlik Ölçeği puanlarında anlamlı bir düşme olduğunu ve bu düşüşün kalıcı olduğunu göstermektedir.

\section{Tartışma ve Sonuç}

Araştırma sonucunda çözüm odaklı yaklaşıma dayalı grupla psikolojik danışmaya katılan öğrencilerin (deney grubu) bu programa katılmayan (kontrol grubu) ve mesleki rehberlik programına katılan (plasebo grubu) öğrencilere göre ruminasyon ve öğrenilmiş çaresizlik düzeylerinde anlamlı bir azalma olduğu bulunmuştur. 
Araştırmanın birinci denencesi "Çözüm odaklı grupla psikolojik danışma yaklaşımına dayalı grupla psikolojik danışma oturumlarına katılan öğrencilerin ruminasyon ön test, son test puan ortalamalarında plasebo ve kontrol grubundaki öğrencilere göre istatistiksel olarak anlamlı bir düşüş olacaktır ve bu düşüş izleme testinde de korunacaktır." Şeklindedir. Elde edilen bulgular araştırmanın ilk denencesini doğrulamaktadır. Buna göre çözüm odaklı yaklaşıma dayalı grupla psikolojik danışmanın lise öğrencilerinin ruminasyon düzeylerini azaltmada etkili olduğu söylenebilir. Bu çalışmaya benzer bir çalışma Sarıçam (2014) tarafından gerçekleştirilmiştir. Çözüm Odaklı Kısa Süreli Yaklaşıma Dayalı Bir Müdahale Programı'nın üniversite öğrencilerinin ruminasyon düzeylerini azalttı̆g 1 ve bu durumun kalıcılık ölçümlerinde de korunduğunu ortaya koymuştur. Bu sonuç araştırmanın bulgularıyla örtüşmektedir.

Literatürde Çözüm Odaklı Psikolojik Danışma Yaklaşımının ruminasyon üzerindeki etkisinin incelendiği başka bir çalışma bulunmadığı için diğer müdahale yaklaşımlarının ruminasyon üzerindeki etkisini inceleyen çalışmalar dikkate alındığında; ruminasyonu azaltmaya yönelik çalışmaların sonuçları bu çalışmanın bulgularıyla benzerlik göstermektedir. Ramel, Goldin, Carmona ve McQuaid (2004), farkındalık meditasyonunun ruminasyonu azalttığını rapor etmişlerdir. Benzer şekilde bilişsel davranışçı terapinin ruminasyonu azaltmada etkili olduğunu gösteren çalışmalar mevcuttur(Watkins, Scott, Wingrove, Rimes, Bathurst ve diğerleri (2007); Watkins, Mullan, Wingrove, Rimes, Steiner ve diğerleri (2011).

Ruminasyonun kaygı ile (Alloy ve diğerleri, 2006; Ko, Yu ve Kim, 2003;) problem çözme ve depresyonla (Yıldız ve Erdeleklioğlu, 2017; Lyubomirsky ve ark., 1999), kaygı ve depresyonla (Erdur-Baker, Özgülük, Turan ve Danışık) ilişkili olduğunu gösteren araştırmalar bulunmaktadır. Lambert, Okiishi, Finch ve Johnson (1998), Gingerich ve Eisengart (2000), İşlek (2006) çözüm odaklı yaklaşıma dayalı psikolojik danışmanın kaygıyı azaltmada etkili olduğunu rapor etmiştir. Sarıcı-Bulut (2008) çözüm odaklı yaklaşıma dayalı psikolojik danışmanın ilköğretim ikinci kademe öğrencilerinin sınav kaygısı ve problem çözme becerileri üzerinde; Sarı ve Günaydın (2016) depresif belirtileri azaltmada etkili olduğu sonucuna ulaşmışlardır. Araştırma sonuçları literatürdeki bulgularla benzerlik göstermektedir.

Araştırmanın ikinci denencesi "Çözüm odaklı grupla psikolojik danışma yaklaşımına dayalı grupla psikolojik danışma oturumlarına katılan öğrencilerin öğrenilmiş çaresizlik ön test, son test puan ortalamalarında plasebo ve kontrol grubundaki ögrencilere göre istatistiksel olarak anlamlı bir düşüş olacaktır ve bu düşüş izleme testinde de korunacaktır." Şeklindedir. Elde edilen bulgular araştırmanın ikinci denencesini de doğrulamaktadır. Buna göre çözüm odaklı yaklaşıma dayalı grupla psikolojik danışmanın lise öğrencilerinin öğrenilmiş çaresizlik düzeylerini azaltmada etkili olduğu söylenebilir. Kök (1992), çocuk esirgeme kurumunda kalan çocuklarla yürütülen grupla psikolojik danışmanın; Avcı, (2009) ortaöğretim öğrencileri ile yürütülen psiko-eğitimin; Kezele (1985) öğrenilmiş çaresizliği azaltmaya odaklanan bir psiko-eğitim uygulamasının öğrenilmiş çaresizlik üzerinde etkili olduğu sonucuna ulaşmıştır. Araştırma sonuçları literatürdeki bulgularla örtüşmektedir.

Ergenlik döneminin; bireylerin kendileri ile ilgili yapılan değerlendirmeleri ve geribildirimleri oldukça önemsendiği bir dönem olması dolayısıyla Çözüm Odaklı Yaklaşım teknikleri arasında bulunan; amigoluk yapma, iltifat etme gibi tekniklerin öğrenciler üzerinde etkili olduğu gözlemlenmiştir. Bunun yanında problemin olmadığ 1 durumlara odaklanma, çözüme ulaşmak için neler yapılması gerektiği üzerinde konuşma, çözüme dönük adım atmaya teşvik etme, içsel kaynaklara odaklanma, güçlü yönlerin keşfedilmesi gibi yöntemlerle öğrencilerin sorunlarını çözmek için harekete geçtikleri gözlenmiştir. Böylece ruminatif düşünceler ve öğrenilmiş çaresizlik duyguları sonucu oluşan olumsuz durumlarla baş etmek adına çaba göstermelerini ve çözüme dönük adımlar atmalarını sağladığı söylenebilir.

Grup sürecinde ergenler grup üyeleriyle sorunlarını paylaşarak, duygu ve düşüncelerini aktarmışlar, birbirlerinin sorunlarını dinleyerek onları anlamaya çalışmışlar, diğer arkadaşlarının da 
benzer sorunlar yaşadıklarını görmüşler, birbirlerine destek olmayı denemişlerdir. Ergenlerin ruminasyon ve öğrenilmiş çaresizlik düzeylerini azaltmada grupla psikolojik danışmada oluşan terapötik ilişkinin de etkisi olduğu söylenebilir. Grup liderinin daha önce Çözüm Odaklı Grupla Psikolojik Danışma oturumlarını yürütmüş olması, asıl uygulamadan önce benzer bir grupla pilot uygulama yapmış olması da liderin deneyim kazanması, grubun özelliklerini ve dinamiklerini tanıması açısından olumlu görülebilir. Plasebo grubunun da araştırmaya dahil edilmesi ve plasebo grubunda mesleki rehberlik çalışmalarının yapılması, deney grubunun puan farklı1ıklarının grup etkisinden kaynaklanıp kaynaklanmadığını test etmek adına önemli sayılabilir.

$\mathrm{Bu}$ çalışmanın bazı sınırlılıkları da bulunmaktadır. Veri toplama yöntemi olarak sadece nicel veriler kullanılmıştır. Nicel verilerin yanında nitel verilerin de (katılımcı günlükleri vb.) kullanılması daha güçlü araştırma sonuçlarına ulaşıımasını sağlayabilir. Bu çalışmada kalıcılık ölçümü son testten 1 ay sonra yapılmıştır. 6 ay sonra veya 1 yıl sonra kalıcılık ölçümlerinin yapılmaması araştırmanın sınırlılıklarından biridir.

$\mathrm{Bu}$ çalışmanın okul psikolojik danışmanları açısından önemli sonuçları bulunmaktadır. Psikolojik danışmanlar tarafından ruminatif düşünce yapısında olan ve çeşitli konularda öğrenilmiş çaresizlik yaşayan öğrenciler tespit edilerek, öğrencilerin bu sorunlarla başa çıkmalarına destek olunabilir. Böylece sıklıkla ruminatif düşünceler içerisinde olan ve öğrenilmiş çaresizlik duyguları yaşayan ergenlerde oluşabilecek anksiyete, depresyon, arkadaşlık ilişkilerinde bozulma, akademik başarıda düşme, zayıf problem çözme becerileri, düşük yaşam doyumu, anksiyete, depresyon gibi problemler çözülebilir.

\section{Öneriler}

Araştırma bulguları göz önüne alındığında, kısa sürede etkili sonuçlar elde edilen çözüm odaklı yaklaşımın okul rehberlik birimlerinde öğrencilerin problemlerinin çözülmesinde kullanılması faydalı olabilir.

Okullarda görev yapan psikolojik danışmanların bilgi ve becerilerini geliştirmeleri için hizmet içi kurslar düzenlenmelidir.

Çözüm odaklı yaklaşıma dayalı grupla psikolojik danışmanın öğrenilmiş çaresizlik üzerindeki etkisini inceleyen bu çalışma bu konuda literatürdeki ilk çalışmadır. Bundan sonra yapılan araştırmalar farklı örneklem gruplarıyla yapılabilir. Böylelikle farklı gruplarda etkililiği test edilmiş olur.

Okul rehberlik birimlerinde öğrencilerin çeşitli problemlerinin üstesinden gelmelerine destek olmak maksadıyla etkililiği test edilmiş konularda çözüm odaklı grupla psikolojik danışma oturumlarının yürütülmesi faydalı olabilir.

Çözüm Odaklı Grupla Psikolojik Danışmanın Lise öğrencilerinin ruminasyon ve öğrenilmiş çaresizlik düzeylerine etkisinin incelendiği bu çalışmanın ortaokul veya üniversite öğrencileri gibi farklı örneklem gruplarıyla yapılması alanyazına katkı sağlayabilir. Aynı programın etkililiği tanı almış bireylerde de test edilebilir.

Ülkemizde ruminasyon ve öğrenilmiş çaresizlik kavramlarıyla yapılan deneysel çalışmaların az olduğu göze çarpmaktadır. Çözüm Odaklı Kısa Süreli Yaklaşım veya diğer yaklaşımlarla yapılacak deneysel çalışmaların ruminasyon ve öğrenilmiş çaresizlik kavramlarına etkilerinin araştırılmasının faydalı olacağı düşünülmektedir. 


\section{Kaynakça}

Abela, J.R.Z., Vanderbilt, E. Rochon, A. (2004). A test of the integration of the response styles and social support theories of depression in third and seventh grade children. Journal of Social and Clinical Psycholog. 23(5): 653-674. https://doi.org/10.1521/jscp.23.5.653.50752

Alloy, L. B., Abramson, L. Y., Hogan, E., Whitehouse, W. G., Rose, D. T., Robinson, M. S., Kim, R. S. ve Lapkin, J. B. (2000). The Temple- Wisconsin cognitive vulnerability to depression project: lifetime history of axis 1 psychopathology in individuals at high and low cognitive risk for depression. Journal of Abnormal Psychology. 109 (3), 403-418. https://psycnet.apa.org/fulltext/1973-26160-001.pdf (12 Mart 2015). https://doi.org/10.1037/0021-843x.109.3.403

Ateş, B. (2014). Üniversite öğrencilerinin sosyal fobi ile başa çıkmalarında çözüm odakl grupla psikolojik danışmanın etkisinin incelenmesi. Yayınlanmamış Doktora Tezi. Atatürk Üniversitesi, Eğitim Bilimleri Enstütüsü. Erzurum.

Avc1, D. (2009). Öğrenilmiş iyimserlik eğitim programının 9. ve 10. sınıf öğrencileri iyimserlik düzeylerine etkisi. Yayımlanmamış yüksek lisans tezi, Gazi Üniversitesi, Eğitim Bilimleri Enstitüsü, Ankara.

Aydın, G. (1988). 'Depresyonda bilişsel değerlendirme: DYBÖ yetişkin formunun klinik geçerlilik ve güvenirliği'. Nöroloji Nöroşirürji Psikiyatri Dergisi. 3 (3), 135-138.

Bauchemin, J. (2015). Examining the effectiveness of a short-term solution-focused wellness group iıntervention on perceived stress and wellness among college students. Yayınlanmamış Yüksek Lisans Tezi. The Ohio State University.

Büyüköztürk, Ş. (2012). Sosyal Bilimler için Veri Analizi El Kitabı. Pegem Akademi Yayınları. Ankara. https://doi.org/10.14527/9789756802748

Coakes, S.J. (2005). SPSS 12.0 for Windows: Analysis without anguish. Australia: John Wiley.

Çitemel, N. (2014). Çözüm Odaklı grupla psikolojik danışma uygulamaları. Nobel Yayıncılık, Ankara.

Çokluk, Ö., Şekercioğlu, G. ve Büyüköztürk, Ş. (2010). Sosyal bilimler için çok değişkenli istatistik. Tek ve çok değişkenli dă̆llımlar için sayıltıların analizi, lojistik regresyon analizi, diskriminant regresyon analizi, küme analizi, açımlayıcı faktör analizi, doğrulayıcı faktör analizi, yol analizi. Ankara. Pegem.

Dwayne, S. (1996). Relationship between learned helplessness and urban adolescent problem behavior (Unpublished Doctorate Dissertation). The State University of New Jersey. USA.

Dweck, C. S. ve. Repucci, N., D. (1973). Learned helplessness and rein forcement responsibility in children. Journal of Personality And Social Pshychology. 35, 27-34. https://psycnet.apa.org/fulltext/1973-26160-001.pdf (12 Mart 2015 ).

Ellis, M.R. (2005). Relationship between parenting styles and children's motivational style: The development of learned helplessness (Unpublished Master Dissertation). The University of Kansas.

Erdur Baker, Ö.,Özgülük, S.B, Turan, N., Demirci Danışık, N. (2009). Ergenlerde görülen psikolojik belirtilerin yordayıcıları olarak ruminasyon ve öfke/öfke ifade tarzları. Türk Psikolojik Danışma ve Rehberlik Dergisi. 4, 43-53.

Erdur Baker, Ö., Bugay, A. (2012). The Turkish version of the ruminative response scale: An examination of its reliability and validity. The International Journal of Educational and Psychological Assessment, 10(2), 1-16 
Gingerich, W. J. ve Eisengart, S. (2000). Solution focused brief therapy: A review of the outcome research. Family Process. 39, 477-498. https://doi.org/10.1111/j.1545-5300.2000.39408.x

Gingerich, W. J. ve Wabeke, T. (2001). A solution-focused approach to mental health intervention in school setting. Children ve Schools. 23(1), 33-47. https://doi.org/10.1093/cs/23.1.33

İlbay, A.B. (2014). Çözüm odaklı grupla psikolojik danışma uygulamaları. Nobel Yayıncılık, Ankara.

İkiz, F.E, ve Çınkı, Ö. S (2016). Ergenlerin Ruhsal Belirtileri İle Duygusal Öz-Yeterlik Düzeylerinin Incelenmesi. International Periodical for the Languages, Literature and History of Turkish or Turkic Volume 11/14 Summer 2016. https://doi.org/10.7827/turkishstudies.9725

İşlek, M. (2006). Çözüm odaklı yaklaşımlara göre düzenlenmiş sınav kaygıslyla başa çıkma eğitim programının üniversiteye hazırlanan ögrencilerin sınav kaygısı düzeylerine etkisi. Yayınlanmamış yüksek lisans tezi. Hacettepe Üniversitesi Sosyal Bilimler Enstitüsü.

Kezele, G. L. (1985). Psycho-educational intervention with learned helplessness: An analysis of attributional factors of learning disabled adolescents in conjunction with composing written language tasks in the academic setting. Unpublished doctoral dissertation, Marquette University, Milwaukee, USA. http://search.proquest.com/pqdtft/docview/303360009/fulltextPDF. (12 Mart 2015)

Ko, M. J., Yu, S. J. ve Kim, Y. G. (2003). The effects of solution-focused group counseling on the stress response and coping strategies in the Delinquent Juveniles. Journal of Korean Academy of Nursing. 3, 440-450. https://doi.org/10.4040/jkan.2003.33.3.440

Kök, M. (1992). Psikolojik danışmanın dezavantajlı çocukların öğrenilmiş̧ çaresizlik, benlik tasarımı ve genel kaygl düzeylerine etkisi. Yayımlanmamış doktora tezi, Atatürk Üniversitesi, Sosyal Bilimler Enstitüsü, Erzurum.

Lambert, M. J., Okiishi, J. C., Finch, A. E. ve Johnson, L. D. (1998). Outcome Assessment: From Conceptualization to Implementation. Professional Psychology: Research and Practice, 29, 63-70. https://doi.org/10.1037/0735-7028.29.1.63

Lyubomirsky, S., Tucker, K. L., Caldwell, N.D. ve diğerleri. (1999). Why ruminators are poor problem solvers: Clues from the phenomenology of dysphoric rumination. Journal of personality and Social Psychology. 77, 1041-1060. https://doi.org/10.1037/00223514.77.5.1041

Nolen-Hoeksema, S., Girgus, J. S., ve Seligman, M. E. P. (1986). Learned helplessness in children: A longitudinal study of depression, explanatory style and academic achievement. Journal of Personality and Social Psychology. 51, 435-442. https://psycnet.apa.org/fulltext/198631259- 001.pdf (12 Mart 2015 ). https://doi.org/10.1037/0022-3514.51.2.435

Nolen-Hoeksema, S. ve Morrow, J. A. (1991). Prospective study of depression and posttraumatic stress symptoms after a natural disaster: The 1989 Loma Prieta Earthquake. Journal of Personality and Social Psychology. Vol. 61, No. 1,115-121. https://doi.org/10.1037/00223514.61.1.115

Özyurt, B. (2010). Gelişim Konularına genel bakış. (A. Kaya, ed.) Eğitim Psikolojisi. 4. Baskı (ss: 1-28). Ankara: Pegem Akademi. https://doi.org/10.14527/9789944919500.01

Quick, E. K. (2013). Solution Focused Anxiety Management. A Treatment and Training Manual. San Diego: Elsevier Academic Press. 
Papagergiou, C. ve Wells, A. (2004). Depressive rumination; nature, theory and treatment. Jon Wiley\&Sons.Ltd.

Ramel, W., Goldin, P. R., Carmona, P. E. ve McQuaid, J. R. (2004). The effects of mindfulness meditation on cognitive processes and affect in patients with past depression. Cognitive Therapy and Research, 28, 433-455. https://doi.org/10.1023/b:cotr.0000045557.15923.96

Razali, N. M., Wah, Y. B. (2011). Power Comparisons of Shapiro-Wilk, Kolmogorov-Smirnov, Lilliefors and Anderson-Darling Tests. Journal of Statistical Modeling and Analysis. 2(1), 21-33

Rippere, V. (1977). "What's the thing to do when you're feeling depressed?" A pilot study. Behaviour Research and Therapy, 15,185-191. https://doi.org/10.1016/00057967(77)90104-8

Sarı, E., ve Günaydın, N. (2016). Effectiveness of solution-focused coping with depression training on depression symptoms. Anatolian Journal of Psychiatry. 17(5), 369-375. https://doi.org/10.5455/apd.208951

Sarıcı Bulut, S. (2008). İlkögretim ikinci kademe öğrencilerinin sınav kaygıları, saldırganlık eğilimleri ve problem çözme becerilerindeki yetersizliklerin sağaltımında grupla çözüm odaklı kisa terapinin etkileri. Yayınlanmamış doktora tezi. Atatürk Üniversitesi Sosyal Bilimler Enstitüsü.

Sarıçam, H. (2014). Çözüm odaklı kısa süreli yaklaşıma dayalı bir müdahale programının ruminasyon üzerinde etkisi. Yayınlanmamış doktora tezi. Sakarya Üniversitesi Eğitim Bilimleri Enstitüsü. https://doi.org/10.26466/opus.406195

Seligman, M.E.P. (2007). Öğrenilmiş iyimserlik (Çev. S. Kunt Akbaş). Ankara: HYB Yayıncılık.

Siyez, D.M. (2010). Ergenlerde problem davranışlar (2. baskı). Ankara: Pegem Akademi.

Tabachnick, B.G. ve Fidell, L.S. (2001). Using multivariate statistics. Boston: Allyn and Bacon.

Taylor, W.F. (2013). Effects of solution-focused brief therapy group counseling on generalized anxiety disorder. Yayınlanmamış Doktora Tezi. Walden University.

Treynor, W., Gonzalez, R., \& Nolen-Hoeksema, S. (2003). Rumination reconsidered: A psychometric analysis. Cognitive Therapy and Research. 27(3), 247-259.

Tuna, D. (2012). Çözüm odaklı kısa süreli yaklaşıma dayalı öfke kontrolü eğitim programının lise ögrencilerinin öfke kontrolü ve iletişim becerileri düzeylerine etkisi. Yayınlanmış yüksek lisans tezi. Dokuz Eylül Üniversitesi. Eğitim Bilimleri Enstitüsü. İzmir.

Ulusoy, Y. ve Duy, B. (2013). “Öğrenilmiş iyimserlik psiko-eğitim uygulamasının öğrenilmiş çaresizlik ve akılcı olmayan inançlar üzerindeki etkisi” Kuram ve Uygulamada Eğitim Bilimleri, Educational Sciences: Theory \& Practice - 13(3), 1431-1446. https://doi.org/10.12738/estp.2013.3.1469

Uysal, R. (2014). Çözüm Odaklı Grupla Psikolojik Danışma Uygulamaları. Nobel Yayıncılık, Ankara.

Watkins, E. R., Mullan, E., Wingrove, J., Rimes, K. A., Steiner, H. ve diğerleri (2011). Rumination-focused cognitive-behavioural therapy for residual depression: Phase II randomised controlled trial. The British Journal of Psychiatry, 199(4), 317-322. https://doi.org/10.1192/bjp.bp.110.090282.

Watkins, E. R., Scott, J., Wingrove, J., Rimes, K. A., Bathurst, N., Steiner, H. ve diğerleri. (2007). Rumination-focused cognitive behaviour therapy for residual depression: A Case Series.

www.turkishstudies.net/social 


Behaviour Research and Therapy, 45(9), 2144-54.

https://doi.org/10.1016/j.brat.2006.09.018

Yavuzer, H. (2005). Çocuk Psikolojisi. Remzi Kitabevi, İstanbul.

Yıldız, M. ve Erdeleklioğlu, J. (2017). Üniversite öğrencilerinin depresyon düzeylerinin ruminasyon ve problem çözme becerileriyle ilişkisi. Kalem Ĕgitim ve İnsan Bilimleri Dergisi. 2019, 9 (1). https://doi.org/10.23863/kalem.2018.97

Zhang, W., Yan, T.T., Du, Y.S., ve Liu, X.H. (2014). Brief Report: Effects of solution-focused brief therapy group-work on promoting post-traumatic growth of mothers who have a child with asd. autism dev disord (2014) 44:2052-2056. https://doi.org/10.1007/s10803-0142051-8 